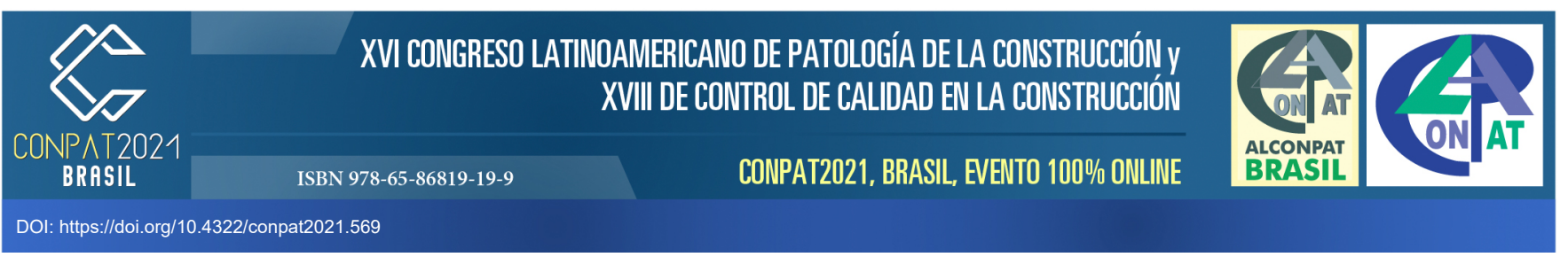

\title{
CORROSÃO NA CAPELA DE SANTA EDWIRGES
}

\author{
J. C. Sales ${ }^{1 *}$ \\ *email: juscelinochaves@hotmail.com \\ ${ }^{1}$ Departamento de Engenharia Civil, Universidade Estadual Vale do Acaraú, Sobral, Brasil
}

\section{RESUMO}

As edificações próximas ao litoral marinho sofrem mais com os ataques do meio em que foram construídas bem como as edificações construídas nos ambientes urbanos onde existe uma poluição acentuada devido a emissão de $\mathrm{CO}_{2}$. O presente trabalho faz uma análise da manifestação patológica corrosão na armadura na Capela de Santa Edwirges e no edifício paroquial localizados na cidade de Fortaleza. Foi possível concluir que a corrosão na armadura das lajes e dos pilares das edificações ocorreram devido ao spray marinho que gera íons cloretos (ataque por cloretos) que acarreta também corrosão por pites nas estruturas metálicas como também a carbonatação do concreto que ocorre ao longo de toda a barra de aço da armadura, onde a carbonatação é bastante agressiva devido as edificações estarem localizadas em uma área onde transita muitos veículos que liberam $\mathrm{CO}_{2}$ devido seus motores de combustão interna. As edificações estão localizada a menos de $10 \mathrm{~m}$ do mar.

Palavras-chave: corrosão na armadura, spray marinho, carbonatação, íons cloretos, Capela de Santa Edwirges.

\section{ABSTRAT}


Buildings close to the sea coast suffer more from attacks from the environment in which they were built, as well as buildings built in urban environments where there is a marked pollution due to $\mathrm{CO}_{2}$ emissions. The present work analyzes the pathological manifestation of corrosion in the armor in the Chapel of Santa Edwirges and in the parish building located in the city of Fortaleza. It was possible to conclude that the corrosion in the reinforcement of the slabs and pillars of the buildings occurred due to the marine spray that generates chloride ions (attack by chlorides) that also causes pitting corrosion in the metallic structures as well as the carbonation of the concrete that occurs throughout the entire structure. the steel bar of the armature, where carbonation is quite aggressive due to the buildings being located in an area where many vehicles that release $\mathrm{CO}_{2}$ due to their internal combustion engines transit. The buildings are located less than $10 \mathrm{~m}$ from the sea.

Keywords: armor corrosion, marine spray, carbonation, chloride ions, Santa Edwirges Chapel.

\section{INTRODUÇÃO}


O concreto armado é a solução estrutural mais empregada nas construções brasileiras e em grande parcela das edificações dos principais países do mundo (Bolina, 2019).

A carbonatação ocorre primeiramente na superfície e avança em direção ao interior do concreto e, quando alcança a armadura, ocorre a despassivação e corrosão dela. A corrosão do aço faz com que seu volume aumente, causando fissuração do concreto, destacamento do cobrimento, redução da área de aço e perda da aderência do aço com o concreto (Carvalho, 2020).

A corrosão das barras de aço de concreto armado tem afetado negativamente a construção civil, causando tanto perdas econômicas como perdas humanas. A corrosão ocorre, principalmente, devido à ação agressiva do dióxido de carbono $\left(\mathrm{CO}_{2}\right)$ e dos íons cloreto $\left(\mathrm{Cl}^{-}\right)$sendo que a corrosão desencadeada pelo $\mathrm{CO}_{2}$ ocorre em qualquer tipo de atmosfera, desde que o concreto não permaneça saturado continuamente, enquanto a corrosão por $\mathrm{Cl}^{-}$ocorre, no Brasil quase que exclusivamente em atmosfera marinha (Pacheco, 2017).

Pesquisadores fizeram a estimação probabilística do tempo inicial de corrosão da armadura de peças de concreto armado submetidas a ataque por íons cloretos, aplicando o Método de Monte Carlo em uma edificação situada em zona marinha e as medições foram efetuadas pelo processo da vela úmida (Oliveira, 2011).

A corrosão de armaduras é um problema mundial, especialmente em construções expostas a ambientes agressivos como a água do mar ou os saia de degelo. Utilizando o ensaio de não destrutivos de resistividade elétrica utilizada na avalição da corrosão do aço no concreto armado, pesquisadores concluíram que quanto maior o teor de cloretos, menor a resistividade (Real, 2014). A avaliação do teor crítico de cloretos em concreto armado é importante pois o íon cloreto é um dos agentes mais agressivos no processo corrosivo do concreto armado. Foi analisada a relação água/cimento com adição de sílica e metacaulin submetidos ao ataque químico em uma solução com cloreto de sódio $(\mathrm{NaCl})$ e foi constatado que a água/cimento e a sílica e o metacaulin, foram fatores determinantes para abreviar o período de início de corrosão (Neri, 2014).

Pesquisadores analisaram o comportamento de concreto armado com a adição de resíduos de tijolos cerâmicos (RTM) frente à corrosão por cloretos e concluíram que houve uma diminuição na resistência mecânica e no teor de cloreto para os concretos com RTM (Pereira, 2014).

A Capela dos Aflitos, de 1774, na cidade de São Paulo é o testemunho restante do primeiro cemitério público da cidade. Hoje, enfrenta problemas como rachaduras e queda do reboco, mas continua atraindo fiéis, especialmente de Chaguinhas, santo popular que teria sido morto na forca injustamente (Mengue, 2019).

Pesquisadores conseguiram propor soluções de durabilidade na vida útil de projeto de estruturas de concreto armado sujeitas a ataque de cloretos (Mees, 2020).

Foi comparada por pesquisadores a utilização de inibidores de corrosão a base de carboxilato de amina, o aumento no cobrimento, a redução da relação água/cimento e a adição de sílica ativa, na vida útil de projeto de estruturas de concreto armado situadas em ambientes salinos por conta da corrosão das armaduras (Mees, 2020).

Neri et al (2013) avaliaram estruturas de concreto submetidas ao ataque de cloreto de sódio e ácido sulfúrico e concluíram que a relação $(\mathrm{a} / \mathrm{c})$ e o tipo de solução agressiva foram fatores determinantes para a corrosão do aço.

Diferentemente do que ocorre com a ação de íons cloretos onde a oxidação se dar por pites, ou seja, incidências pontuais, a carbonatação se dar de forma generalizada ao logo da superfície da barra atingida (Oliveira, 2013).

A corrosão na armadura das lajes lisas, das vigas e dos pilares nas estructuras de concreto armado das edificações sempre existirá, como também a corrosão existirá em estrutruras metálicas.

O presente trabalho teve como objetivo analisar a manifestação patológica da corrosão na Capela de Santa Edwirges e do edifício paroquial, mostrando o efeito do ambiente e as causas da 
manifestação patológica da corrosão nas edificações, e o porque da aceleração do processo corrosivo.

\section{METODOLOGIA}

O presente trabalho foi realizado através de um estudo de caso através de uma inspeção in situ feita na Capela de Santa Edwirges para detectar as manifestações patológicas de corrosão das armaduras e corrosão nos equipamentos feitos de aço mostrando as causas e o porquê de terem ocorridos essas manifestações patológicas.

Foram feitos também registros fotográficos das manifestações patológicas existentes na Capela de Santa Edwirges, como também uma pesquisa de cunho bibliográfico.

\section{CORROSÃO NA CAPELA DE SANTA EDWIRGES}

A corrosão no ambiente marinho é bem mais acelerada do que em outras regiões devido ao ataque do cloreto de sódio (íons cloretos) existente as ondas do mar (água salgada).

Existem vários métodos de combate a corrosão como a proteção por barreira a base de tintas (zarcão, ferrolack vermelho óxido (tinta à base de óxido), proteção catódica, ânodo de sacrifício etc.

A Figura 1 mostra a névoa (spray) gerada pelas ondas na praia, que possuem grande quantidade de íons cloretos ( $\mathrm{NaCl}$-cloreto de sódio), que vão atacar as estruturas tanto de concreto armado como também as estruturas metálicas, mostrando assim que essas edificações são construídas em um ambiente muito agressivo e diminui assim a vida útil das edificações. É possível também constatar a existência de um muro de quase um metro de largura e $1,5 \mathrm{~m}$ de altura que foi construído entre as pedras de enrocamento da praia e da Capela de Santa Edwirges que fica a menos de 6m do muro.

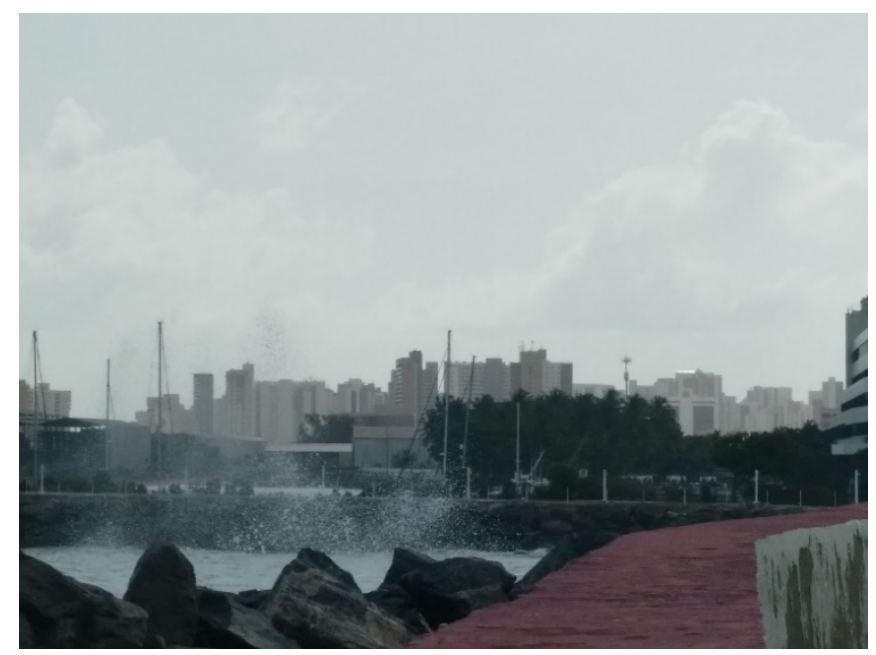

Figura 1. Névoa (spray marinho) gerada pelas ondas na praia e o muro. Fonte: própia, 2019.

Tanto na cerca feita de estrutura metálica que separa a área da Igreja de Santa Edwirges da calçada da Avenida Leste-Oeste como todos os outros equipamentos feitos de aço apresentaram acelerado processo corrosivo. Na Figura 2 foi possível constatar grades de proteção da edificação em alto grau de corrosão onde quase todas as grades têm que ser trocadas pois a oxidação (corrosão) diminuiu o diâmetro das barras de aço carbono 1020 (liga metálica) e também foi possível perceber a Avenida Leste-Oeste que é um local onde se libera muito $\mathrm{CO}_{2}$ para a atmosfera. 


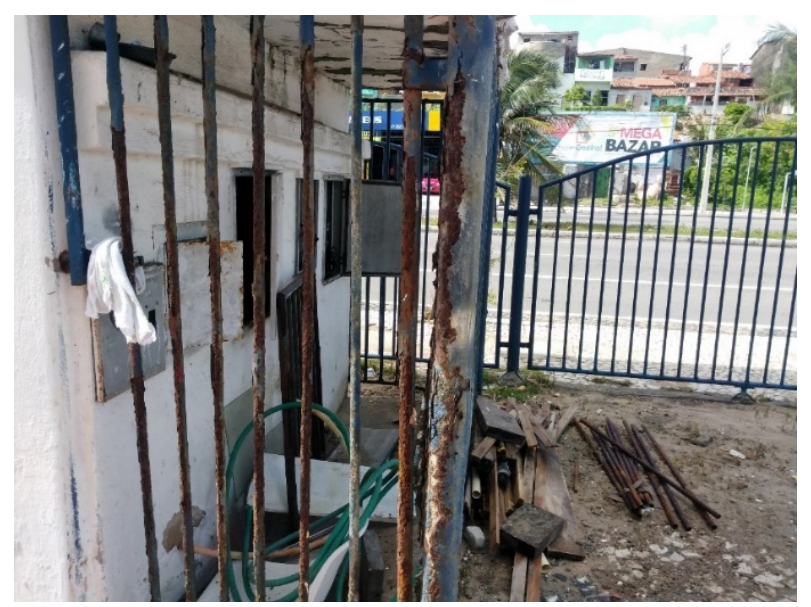

Figura 2. Grades de proteção da edificação com alto grau de corrosão. Fonte: própia, 2019.

A Figura 3 mostra uma grade de proteção que fica em frente à Igreja de Santa Edwirges com muitos pontos de corrosão por pites principalmente devido ao ataque dos íons cloreto como também muita corrosão bem na base do pilar feito de aço, que serve de sustentação da grade no solo (piso cerâmico) e em algumas barras de aço. O aço carbono 1020 é um material muito susceptível a corrosão (oxidação) pois no ar temos o oxigênio que tem uma grande afinidade pelo ferro que é o elemento químico que está presente no aço em grande quantidade, inclusive no caso das estruturas analisadas chega a mais de $97 \%$ de ferro (aço carbono 1020). Como sobre os equipamentos (edificações em concreto armado, estruturas de aço) analisados além do oxigênio do ar temos uma grande quantidade de íons cloretos, isso vai acelerar ainda mais a corrosão. O aço carbono 1020 é uma liga metálica que tem em sua composição química com $0,2 \%$ de carbono.

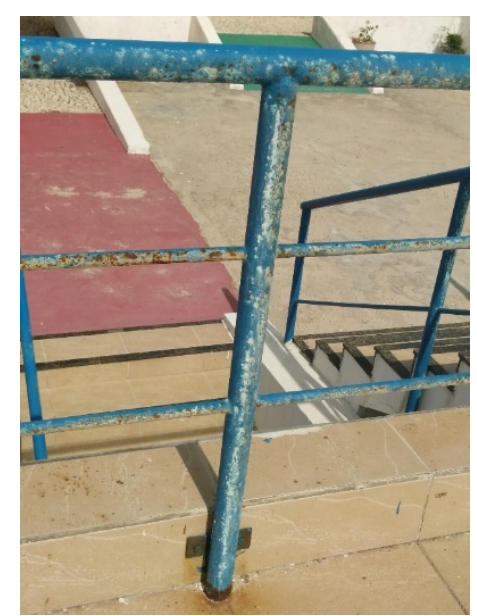

Figura 3. Grade de proteção que fica em frente à Igreja de Santa Edwirges com muitos pontos de corrosão por pites. Fonte: própia, 2019.

Na Figura 4 foi possível constatar corrosão na armadura da viga lateral da Igreja de Santa Edwirges como também uma trinca na viga e a retirada do cobrimento de concreto sobre o aço da viga que se encontrava corroída. Foi possível constatar também que a viga lateral foi passada a cal virgem sem ter sido feito o enchimento com concreto do vazio deixado pelo desplacamento do concreto. A corrosão também pode ser vista em toda as partes da antena fabricada de aço que fica fixada na viga. Foi possível perceber o destacamento de parte do concreto (cobrimento) em dois locais da viga, ou seja, no local da lateral da viga que foi pintada de branco como também na parte inferior direita (ponta da viga) da viga de concreto armado onde é possível ver a armadura exposta. 


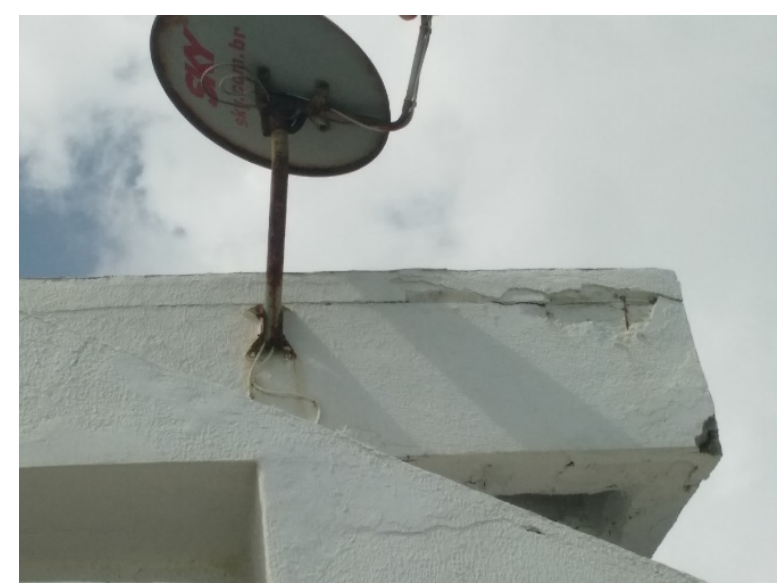

Figura 4. Corrosão na armadura da viga lateral da igreja com destacamento de parte do concreto (cobrimento). Fonte: própia, 2019.

Na Figura 5 foi possível constatar as armaduras em uma das vigas de concreto armado altamente comprometidas pela corrosão. Essa viga do edifício paroquial fica localiza a menos de $8 \mathrm{~m}$ do mar. O concreto também sofreu carbonatação pois a viga está a menos de $40 \mathrm{~m}$ da avenida Leste-Oeste. A detecção da manifestação patológicas da corrosão foi feita no dia 30 de maio de 2018. A corrosão na armadura já bastante agressiva em uma das lajes da edificação também pode ser vista, onde é possível constatar também o desplacamento da camada de cobrimento da laje de concreto armado. O destacamento do cobrimento da armadura acelera a corrosão da armadura (vergalhão de aço).

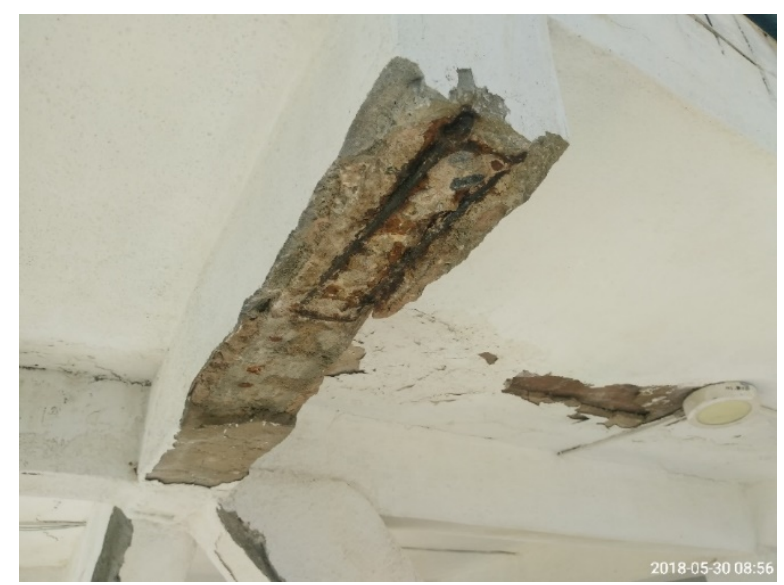

Figura 5. Armaduras em uma das vigas de concreto armado altamente comprometidas pela corrosão. Fonte: própia, 2018.

Devido a corrosão da armadura foi feita uma intervenção no dia 8 de junho de 2018 onde foi possível constatar a recuperação das vigas como pode ser visto na Figura 6, onde primeiramente foi colocada tinta epoxi para armadura de aço carbono, que são tintas que resistem à umidade, a imersão em água salgada como também o spray marinho que possui íons cloretos e depois foi feito o recobrimento da armadura com concreto.

Para reparar os efeitos da carbonatação nas vigas da edificação não se utilizou a realcalinização (eletroquímica, química ou passiva) e sim o reparo convencional. 


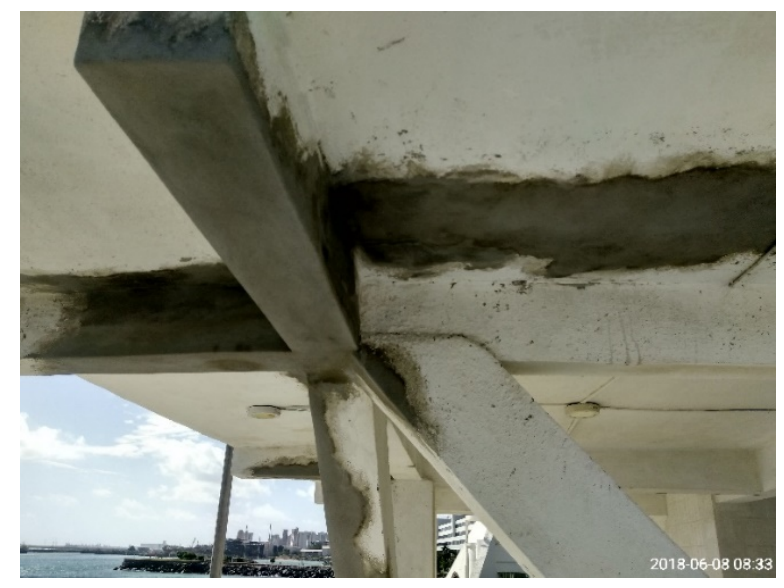

Figura 6. Recuperação das vigas (método convencional). Fonte: própia, 2018.

A Figura 7 é possível perceber a edifício paroquial e o mar onde as ondas ficam a menos de $10 \mathrm{~m}$ da edificação acelerando a corrosão pela ação dos íons cloretos. É também possível perceber no segundo pavimento da edificação a existência de armadura exposta no pilar com o destacamento do cobrimento de concreto onde parte do revestimento cerâmico já foi destacado. Também foi possível perceber corrosão por pites em todas as barras de aço carbono 1020 de todas as varandas da edificação.

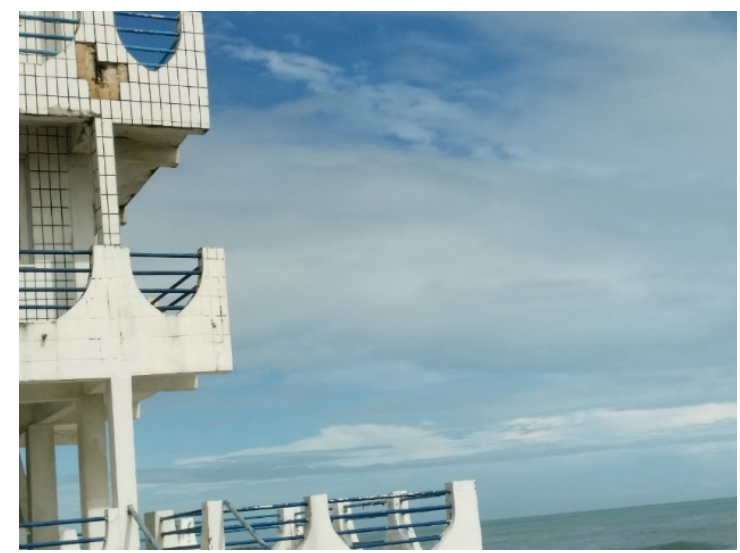

Figura 7. Edifício paroquial e o mar onde as ondas ficam a menos de $10 \mathrm{~m}$ da edificação. Fonte: própia, 2019.

As manutenções são feitas com frequências para que a corrosão da armadura não venha danificar mais ainda a estrutura. Na Figura 8 é possível perceber um operário fazendo o reparo convencional da corrosão na armadura em uma viga de contraventamento que tinha manifestação patológica de corrosão da armadura. Foi feito novamente o recobrimento com concreto. 


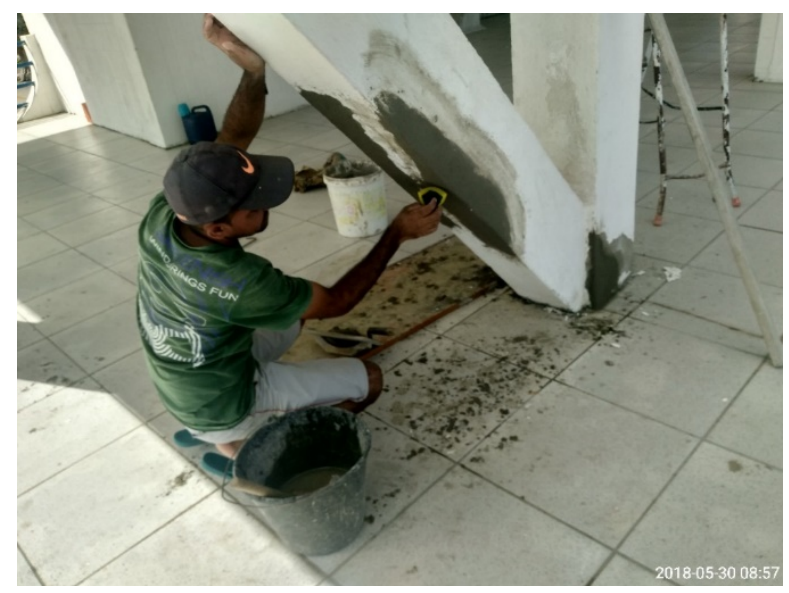

Figura 8. Operário fazendo o reparo convencional da corrosão na armadura em uma viga de contraventamento. Fonte: própia, 2018.

Na Figura 9 foi possível constatar a recuperação dos pilares de sustentação da edificação como também o contraventamento (duas vigas inclinadas em $45^{\circ}$ ) em concreto armado que sofreram com o processo corrosivo da armadura. $\mathrm{O}$ concreto foi aplicado para depois as vigas serem pintadas. $\mathrm{O}$ contraventamento é necessário porque a edificação está em um local onde a velocidade dos ventos e bem maior devido estar localizada em uma praia, onde inclusive a cerca de $3 \mathrm{~km}$ de distância existe um parque eólico instalado gerando energia eólica. As vigas contraventadas partem da base de dois pilares e sustentam duas vigas longitudinais que ficam perpendicular uma da outra.

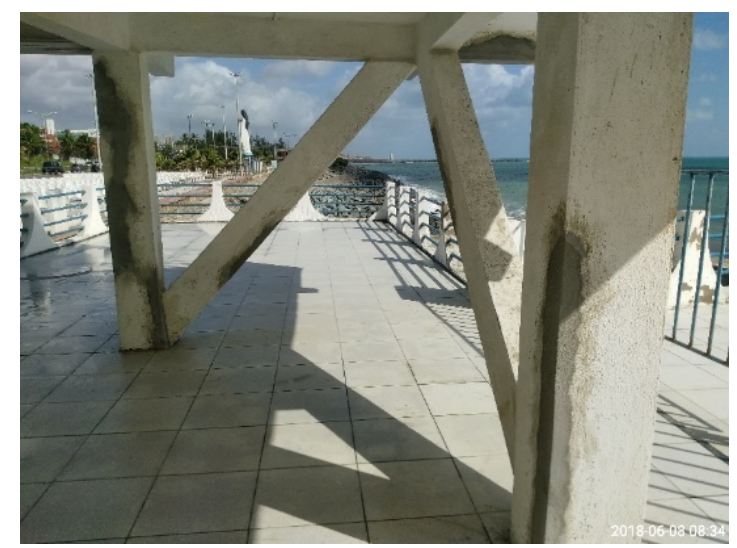

Figura 9. Recuperação dos pilares de sustentação da edificação. Fonte: própia, 2018.

A profilaxia anteriormente proposta foi executada onde foi possível perceber tanto em parte da laje lisa como nas vigas que foi feito a inserção de concreto sobre as áreas deterioradas onde também é possível perceber que o concreto ainda está fresco, para posteriormente se passar a cal virgem sobre a sua superfície. A recuperação da corrosão da armadura das lajes lisas da edificação foi feita pelo método convencional e eram bastante acentuadas, como também na viga de contraventamento tinha a manifestação patológica (Figura 10). 


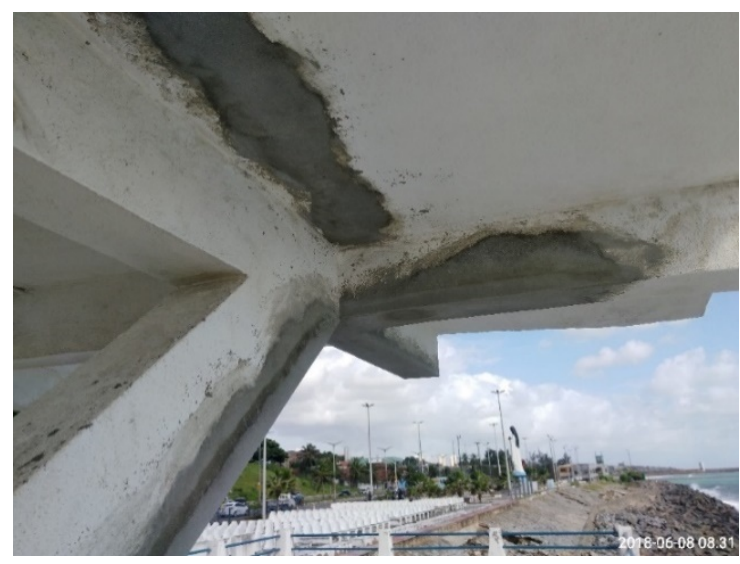

Figura 10. Recuperação da corrosão na armadura das lajes lisas da edificação que era bastante acentuada. Fonte: própia, 2018.

Foi possível também encontrar pontos de corrosão no pregos que foram fixado na fachada da edificação sobre o revestimento cerâmico (cor amarelada) como também nos parafusos de fixação da janela (Figura 11). Os pregos feito de aço carbono 1020 foram fixados para colocar cordões ligando a Capela de Santa Edwirges ao edifício paroquial para se fixar as bandeirinhas no dia da festa da padroeira Santa Edwirges. Também foi possivel detectar que os pregos de fixação da janela estavam corridos.

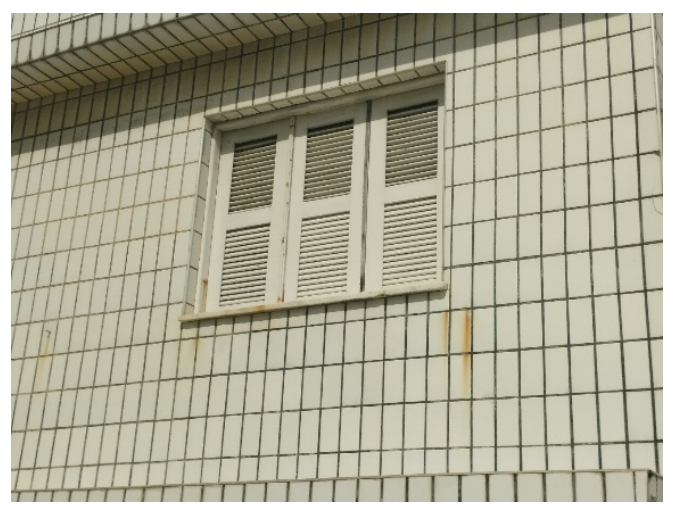

Figura 11. Corrosão nos pregos que foram fixado na fachada da edificação sobre o revestimento cerâmico. Fonte: própia, 2019.

Como o ataque da maresia é muito incisivo, na Figura 12 é possível perceber a corrosão da tubulação de aço carbono 1020, fixada em um poste de concreto armado e com a caixa de medição de energia. A corrosão está em estado muito avançado. Também é possível perceber os veículos transitando e emitindo $\mathrm{CO}_{2}$ na Avenida Leste-Oeste muito próximo as estruturas de concreto armado. 


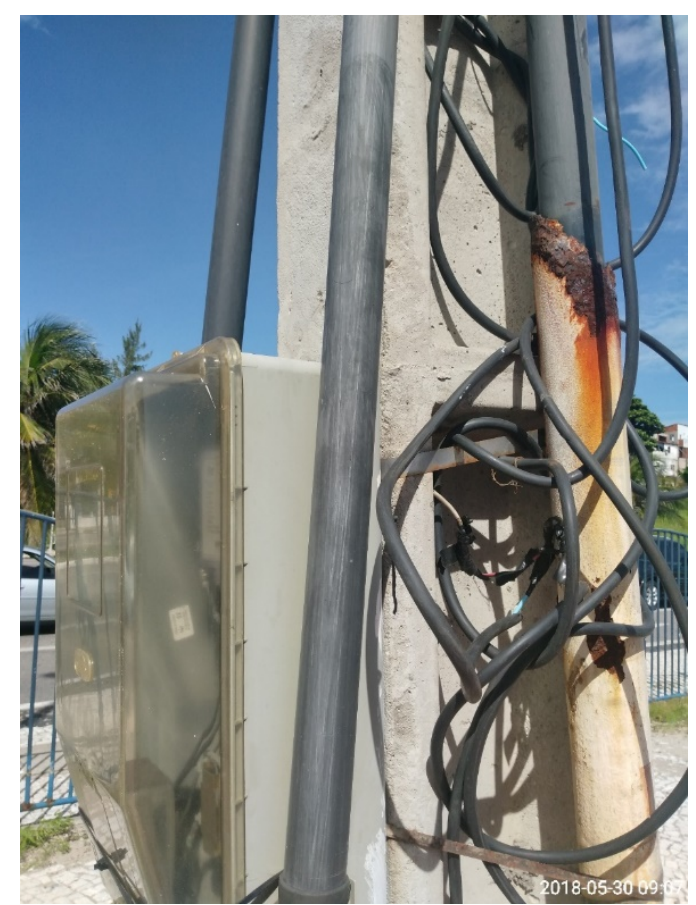

Figura 12. Corrosão da tubulação de aço fixada em um poste de concreto armado. Fonte: própia, 2018.

A praia do Futuro também localizada na cidade de Fortaleza possui a segunda maior salinidade do mundo só perdendo para o Mar Morto localizado na Ásia.

A corrosão como também a captura de carbono no concreto para a durabilidade das armaduras devem ser estudas com a mais ênfase para que as estrutura de concreto como também as estruturas metálicas (corrosão) tenham uma maior vida útil.

Os efeitos dos sais marinhos nas construções foram possíveis ser percebido nas edificações como a Capela de Santa Edwirges e edifício paroquial e os equipamentos feitos de aço acelerando o processo corrosivo das estruturas.

Sabemos que a corrosão por carbonatação e menos incisiva que a corrosão por cloretos no concreto armado. Nos casos dos equipamentos analisados vale ressaltar que de um lado foi possível encontrar o mar gerando íons cloretos (efeitos dos sais marinhos) e do outro lado da Capela de Santa Edwirges e do edifício paroquial temos uma das avenidas mais movimentadas de Fortaleza que é a Avenida Leste-Oeste, onde passam muitos veículos como ônibus, caminhões, automóveis etc. que liberam uma grande quantidade de $\mathrm{CO}_{2}$ devido a queima dos combustíveis fosseis. Esse $\mathrm{CO}_{2}$ vai atacar o concreto gerando a carbonatação dele.

Nas armaduras do concreto armado podemos fazer uma proteção catódica com anodo de sacrifício, como também podemos usar armaduras galvanizadas (colocação de zinco na superfície), armaduras com pintura epóxi (tintas anticorrosivas) e é possível fabricar as armaduras com ligas especiais de aço, ou fabricar armadura de aço inoxidável (com maior quantidade de níquel e cromo no aço) que são bem mais caras.

É importante melhorar a pegada de carbono para diminuir o efeito da carbonatação no concreto armado. Nós devemos aumentar a captura de $\mathrm{CO}_{2}$.

\section{CONCLUSÃO}


As edificações analisadas tanto a Capela de Santa Edwirges como edifício paroquial são fortemente submetidas a ataques por íons cloreto como também aos processos de carbonatação em suas estruturas de concreto pela sua própria localização.

A Capela de Santa Edwirges como edifício paroquial estão cercados pois em um lado foi possível encontrar as ondas do mar liberando íons cloretos (ataque por cloretos), enquanto do outro lado foi possível detectar os veículos liberando $\mathrm{CO}_{2}$ gerando a carbonatação das estruturas.

Foi possível detectar corrosão na armadura dos pilares como também a corrosão na armadura de algumas lajes da edificação (edifício paroquial).

Outros problemas de corrosão encontrados foram nos equipamentos (grades, corrimões, tubulação) feito de aço carbono 1020, onde a corrosão estava em estado muito avançado.

Tem que haver um monitoramento constante das estruturas devido ao ambiente agressivo em que a Capela de Santa Edwirges e o edifício paroquial estão localizados.

O destacamento do cobrimento da armadura devido a carbonatação e aos íons cloretos aceleraram a corrosão da armadura.

A corrosão na Capela de Santa Edwirges apresenta-se de uma forma bastante acelerada devido ao ambiente em que ela foi construida, ou seja, muito próxima ao mar e a um grande fluxo de veículos.

\section{REFERÊNCIAS}

Bolina, F. C., Tutikian, B. F., Helene, P. R. L. (2019). “Patologia das Estruturas”. Editora Oficina de Textos, São Paulo.

Carvalho, M. (2020). "Patologias na Construção Civil - Tipos e Causas". Disponível em: $<$ https://carluc.com.br/manutencao-predial/patologias-na-construcao-civil/>. Acesso em: 07 mai. 2021.

Ferreira, P. R. R., Jeronimo, V. L., Meira, G. R. (2014). “Comportamento de concreto armado com a adição de resíduos de tijolos cerâmicos frente à corrosão por cloretos". X Congreso Internacional sobre Patología y Recuperación de Estructuras, Santiago. Universidad Católica de Chile, v. 1. p. 46.

Mees, H. H., Silva, M. R., Rohden, A. B. (2020). "Soluções de durabilidade na vida útil de projeto de estruturas de concreto armado sujeitas a ataque de cloretos". (Org) Marinho, J. L. A., Mesquita, E. F. T. Patologia das edificações - manifestações nas edificações e no patrimônio histórico. 1. ed. São Paulo: Leud, v. 1. p 105-121.

Mengue, P. (2019). "Degradação e abandono ameaçam igrejas históricas no centro de São Paulo". Jornal o Estado de S. Paulo. Disponível em: $<$ https://saopaulo.estadao.com.br/noticias/geral,degradacao-e-abandono-ameacam-igrejashistoricas-no-centro-de-sao-paulo,70002825276>. Acesso em: 12 mai. 2019.

Neri, K. D., Meira, G. R., Vilar, E. O. (2014). "Avalição do teor crítico de cloretos em concreto armado com adição de pozolanas submetidos a ensaio acelerado". X International Congress about Pathology and Structures Rehabilitation - CINPAR. Santiago, Chile.

Neri, K., Alves, H., Ferreira, P., Meira, G., Vilar, E. (2013). “Avaliação de estruturas concretas submetidas ao ataque de cloreto de sódio e ácido sulfúrico". $55^{\circ}$ Congresso Brasileiro do Concreto. Gramado. 
Oliveira, R., Bittencourt, T. (2011). "Estimação probabilística do tempo inicial de corrosão da armadura de peças de concreto armado submetidas a ataque por ions cloretos". $53^{0}$ Congresso Brasileiro do Concreto. Florianópolis.

Oliveira, R., Zarzar Junior, F., Bittencourt, T. (2013). "Estimação probabilística da vida útil de componentes estruturais de pontes submetidas a carbonatação". 55 Congresso Brasileiro do Concreto. Gramado. 2013.

Pacheco, M. S. et al. (2017). “Armaduras de aço com revestimento dúplex (zinco + epóxi) para o prolongamento de vida útil de armaduras de concreto armado". $14^{\mathrm{a}}$ Conferência sobre Tecnologia de Equipamentos. COTEQ. São Paulo. Disponível em: <file://C:/Users/user/Downloads/COTEQ2017106FINAL.pdf>. Acesso em: 8 de abr. 2021.

Real, L. V., Medeiros, M. H. F. (2014). "Influência dos íons cloretos na resistividade do concreto". $\mathrm{X}$ International Congress about Pathology and Structures Rehabilitation - CINPAR. Santiago, Chile. 